ks. Dominik Jackov ${ }^{1}$

\title{
Rola ojca na podstawie XX homilii św. Jana Złotoustego do Listu do Efezjan
}

Podział obowiązków rodzinnych, które są wyznaczone dla każdego członka rodziny, oraz harmonijne relacje rodzinne są kluczowymi myślami Jana Chryzostoma. Temu zagadnieniu poświęcił on homilie do Listu do Efezjan². Rola ojca w rodzinie wypływa z naśladowania Chrystusa. Jego relacja do żony, zwłaszcza szacunek dla niej, ma być budowana na relacjach Chrystusa do Kościoła. Nazywa rodzinę „małym Kościołem”, porównując ją do Kościoła jako Ciała Mistycznego. Życie „małego Kościoła” jest przeniknięte modlitwą oraz czytaniem Pisma Świętego. Najpierw Mąż - głowa rodziny wykonuje następujące czynności chrześcijańskie: czyta teksty natchnione, czerpie siłę z sakramentu Eucharystii (czyli przystępuje do Komunii Świętej). Natomiast chodzenie do kościoła oraz świętowanie dnia Pańskiego pozostają zwykłą praktyką wszystkich członków parva Ecclesia.

\footnotetext{
1 Dominik Jackov - magister licencjat, od roku 2007 zatrudniony w Wyższym Seminarium Duchownym pw. Ducha Świętego w Gródku Podolskim na Ukrainie (Diecezja Kamieniecko-Podolska), gdzie wykłada patrologię, historię Kościoła, duszpasterstwo rodzin oraz metodologię. Student studiów doktoranckich w Instytucie Historii Kościoła i Patrologii działającym w ramach Wydziału Teologii Katolickiego Uniwersytetu Lubelskiego Jana Pawła II w Lublinie.

2 Jan Chryzostom oprócz XX homilii na Ef 5, 22-24, wygłosił na ten list razem 24 homilie. Różnią się one między sobą pod względem treści. Autor artykułu dla opracowania tematu wybrał tylko XX homilię, która najpełniej ukazuje jego podglądy jako duszpasterza na temat rodziny oraz obowiązków męża jako głowy i ojca rodziny. Por. Joannes Chrysostomus, In epistulam ad Ephesios, 20, 1-9, Patrologia Graeca [dalej: PG], 62, 135-150; Беседа XX на Эфес., 20, 1-9, t. XI, s. 172-190. Ponieważ autor korzystał z jednej serii wydawniczej, rosyjskojęzycznej wersji opera omnia Jana Chryzostoma, w kolejnych przypisach niniejszego atykułu pominęto miejsce wydania kolejnych cytowanych tutaj tomów.
} 


\section{Powołanie do odpowiedzialnej miłości oraz podział obowiązków}

Stworzyciel świata w swojej nieskończonej mądrości stworzył człowieka: mężczyznę i kobietę, którzy wzajemnie od siebie zależąả. Godność człowieka, jedna i rozdzielona, przejawia się w relacjach. Mężczyzna dopełnia kobietę, a ona, będąc równą jemu, dopełnia go własną osobowością

W tym wypadku Chryzostom widzi rolę Boga Ojca, który stwarzając człowieka, rozdzielił obowiązki oraz wyznaczył odpowiednie funkcje dla mężczyzny i kobiety. Bóg stworzył żonę z żebra mężczyzny nie dlatego, by ten nią gardził albo żeby wywyższał się nad nią. Ona, będąc częścią ciała mężczyzny, powinna pamiętać o tym, by być mu poddaną ${ }^{5}$. Wielkim złem według Antiocheńczyka jest bunt oraz nieposłuszeństwo mężczyźnie. Nic tak nie kształtuje relacji mężczyzny do żony, jak prawdziwa oraz rzeczywista akceptacja relacji Chrystusa do Kościoła. Ten ideał u Złotoustego pozostaje podstawowym właśnie dlatego, żeby jak najlepiej wytłumaczyć prawdziwe ojcowstwo mężczyzny w rodzinie ${ }^{6}$.

Dla zgody oraz równości Pan Bóg ustanowił różne stopnie władzy i podzielił życie człowieka na dwie części: na część publiczną - wyznaczoną dla mężczyzn oraz prywatną - dla kobiet. Do każdego mężczyzny należą obowiązki odnoszące się do życia publicznego, m.in. praworządność, ekonomia, służba wojskowa; do kobiecych z kolei zalicza się przędzenie lnu, tkanie, przygotowanie posiłków, pilnowanie porządku w domu.Żona powinna dbać o rodzinę i tym samym zwolnić mężczyznę od uciążliwych obowiązków domowych. Chryzostom zabrania kobietom zarabiać pieniądze poza domem. Taki podział obowiązków jest według niego ustanowiony przez Boga, który zapewnia jedność oraz harmonię w relacjach między mężczy-

3 Por. Joannes Chrysostomus, Spuria. Sermo de caritate, PG 60, 773-776; Выборки из разных слов. Беседа I. О любви, t. XII/1, s. 484.

4 Рог. О. Паскуато, Миряни у Йоана Золотоустого. У Церкві, родині, громаді, Львів 2007, S. 102.

„Dlaczego? Dlatego, że skoro są jednomyślni, to również i dzieci ich wychowują się dobrze, i niewolnicy są dobrze zaopatrzeni, a sąsiedzi, przyjaciele i rodzeństwo nasycają się ich wonnością". Por. Joannes Chrysostomus, In epistulam ad Ephesios, 20, 6, PG, 62, 136; Беседа XX на Э§ec., 20, 1, t. XI, s. 172.

6 Por. Joannes Chrysostomus, In epistulam ad Ephesios, 20, 1, PG, 62, 135-138; Беседа XX на Э§ec., 20, 1, t. XI, s. 172-173. 
zną i kobietą7. W małżeństwie mężczyzna jest jakby królem, a żona - zarzadcą. Do dzieci należy władza trzeciego, a do niewolników - czwartego stopnia ${ }^{8}$. Pan Bóg wyznaczył kobiecie mniejszą część obowiązków, ponieważ ona jest pomocą dla mężczyzny (zob. Rdz 2, 18) $)^{9}$. Jej udział jest potrzebny w wielu sprawach. Zwłaszcza troska żon o sprawy domowe zwalnia mężczyznę od tych uciążliwych obowiązków.

Żona pomaga mężowi prowadzić życie cnotliwe. Dzięki niej staje się on ojcem rodziny ${ }^{10}$. Ona troszczy się o sprawy domowe, czuwa nad pracą domowników oraz służby domowej. Dlatego Antiocheńczyk zwraca się z prośbą do męża, aby pomógł żonie w sprawach duchowych, w jakich może mieć przewagę nad kobietą ${ }^{11}$.

Bóg wyznaczył mężczynę na głowę. Żona zaś w rozumieniu św. Jana Chryzostoma została stworzona z żebra Adama. Chociaż w porządku stworzenia zachowują oni równość osób, są różni między sobą. Nie mogą mieć zatem tej samej władzy. Ktoś jest wyższy, a ktoś niższy w porządku zachowania harmonii i równowagi ${ }^{12}$.

W zamian za pokorę żony mąż obdarza ją miłością ze względu na Jezusa Chrystusa, który bez miary pokochał jedyną narzeczoną - Kościół - własne Ciało (zob. Ef 5, 22). Tylko w takim porządku żona powinna korzyć się przed mężem nie ze względu na niego samego, ale ze względu na Chrystusa. Bóg w swoim odwiecznym zamyśle zechciał kobietę podporządkować mężczyźnie (zob. Rdz. 3,16b), ponieważ tam, gdzie występuje równość, brakuje po-

7 Por. О. Паскуато, Миряни у Йоана Золотоустого..., dz. cyt., s. 103; Joannes Chrysostomus, In epistulam ad Ephesios, 20, 4, PG 62, 141; Беседа XX на Эђес., 20, 4, t. XI, s. 178.

8 Por. Joannes Chrysostomus, In epistulam I ad Corinthios, 34, 1, PG 61, 285-286; Беседa XXXIV на 1 Kop. XIII, 13, 8, t. X, s. 359.

9 Por. Joannes Chrysostomus, Ad viduam iuniorem, 4, PG 48, 604; IX. К молодой вдове. Слово второе о воздержании от второго брака, 4, t. I, s. 490.

10 W tym wypadku Złotousty stawia męża w jakości głowy, a żonę w jakości ciała, ponieważ tak zostało przewidziane opatrznością Boga Wszechmogącego. Joannes Chrysostomus, In epistulam ad Ephesios, 20, 1, PG 62, 136; Беседа XX на Эфес., 20, 1, t. XI, s. 172-173.

11 W innym miejscu Złotousty zachęca mężcyzn, żeby pamiętali, iż „od głowy zależy dobra sposobność ciała”. Joannes Chrysostomus, In epistulam ad Ephesios, 20, 4, PG, 62, 139; Беседa ХХ на Эфес., 20, 4, t. XI, s. 178.

12 Por. О. Паскуато, Миряни у Йоана Золотоустого..., dz. cyt., s. 131; „,...] jeżeli mąż jest dobry, jeżeli jest dobrą głową, to w całym ciele nie będzie bezładu [bałaganu]". Joannes Chrysostomus, In epistulam ad Ephesios, 20, 2, PG, 62, 137; Беседа XX на Эфес., 20, 2, t. XI, s. 174. 
koju oraz równowagi. Z tej przyczyny kobieta, która nie poddaje się mężczyźnie, sprzeciwia się Bożym przykazaniom ${ }^{13}$. Chryzostom przekonuje mężów, żeby wady żon nie stawały się główną przyczyną oddalenia ich od siebie ${ }^{14}$.

Ze względu na Boga oraz przestrzeganie Jego przekazań wady oraz różne słabości trzeba znosić cierpliwie. We wszystkich trudnych okolicznościach należy w gorących modlitwach zwracać się do Niego. On okaże miłosierdzie i pomoc, żeby pomóc żonie pozbyć się wad, a męża obdarzy łaską prawdziwego ojcostwa jako owoc za cierpliwość i pokorę. Mąż dlatego zajmuje miejsce głowy, żeby leczyć całe ciało. Żona właśnie dlatego kocha i ceni męża ${ }^{15}$.

Wiele razy kaznodzieja antiocheński prosi mężów, żeby traktowali żony z łagodnością i dobrocią. Cnotliwa oraz łagodna żona jest dla męża pociechą, siłą, radością oraz pomocą. Właśnie dlatego została dana mężowi jako cenna i wolna przez Boga Stwórcę wszechświata ${ }^{16}$.

Żona, zajmując się sprawami domowymi, jeżeli zechce, może poświęcić wiele czasu na modlitwę oraz czytanie Pisma Świętego. Zatopiona w modlitwie oraz pracy, otoczona ciszą oraz szacunkiem domowników, niczym

13 Por. Joannes Chrysostomus, In epistulam ad Ephesios, 20, 2, PG 62, 136-138; Беседа XX на Э§ec., 20, 2, t. XI, s. 174-176; za cnotę najbardziej związaną z pokorą uważał Chryzostom - zgodnie

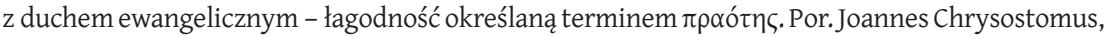
Ecloga 7. De humilitate animi, PG 63, 618; Слово VII. О смиренномудрии, т. XII/1, s. 547; zob. również: M. Szram, Cnota pokory w nauczaniu greckich Ojców Kościoła IV wieku, Lublin 2014, s. 88; M. Szram, Pokora $w$ walce z pycha - fundamentalny spór moralno-duchowy w rozumieniu Ojców Kapadockich i Jana Chryzostoma, „Vox Patrum” 33 (2013) 59, s. 531-345; M. Szram, Terminologia dotyczaca pokory i pychy w pismach greckich Ojców Kościoła IV wieku, „Vox Patrum” 32 (2012) 58, s. 327-342; P. Szczur, Ideał doskonałości chrześcijańskiej według Jana Chryzostoma, „Studia Sandomierskie” 17 (2010) 1-2, s. 197-221; P. Szczur, Zasady pedagogii św. Jana Chryzostoma whomiliach antiochenskich, [w:] Czasy Jana Chryzostoma i jego pasterska pedagogika, red. N. Widok, Opole 2008, s. 168189 (Opolska Biblioteka Pedagogiczna, 105), P. Szczur, Problematyka społeczna w późnoantycznej Antiochii na podstawie nauczania homiletycznego Jana Chryzostoma, Lublin 2008, s. 321-323.

14 Według niego najgorszą wadą jest chciwość. Trzeba szukać tego, co łączy, a nie dzieli. Dostatek materialny według Chryzostoma ma zapewniać mąż. Por. Joannes Chrysostomus, In epistulam ad Ephesios, 20, 3, PG 62, 138-139; Беседа XX на Эфес., 20, 3, t. XI, s. 176-177.

15 Por. Joannes Chrysostomus, In librum ad eos qui scandalizati sunt ob adversitates, 22. [XX. Afflictiones non modo non scandalizzare, sed et prodesse illis qui ex aequo et bono judicent], PG 52, 523-524; Беседа О том, что никому не должно отчаиваться, ни молиться о вреде врагам, ни падать духом, не получая просимого; такжек мужьям о сохранениимирас женами, t. III, s. 403-404.

16 Por. G. Fregni, Miłujciesię czule. Duchowość rodziny według Ojców Kościoła, tłum. D. Wandzioch, Kraków 2002, s. 32-33; Joannes Chrysostomus, In epistulam ad Ephesios, 20, 2, PG 62, 137; Беседa ХХ на Эфес., 20, 2, t. XI, s. 174. 
pustelnik przebywa w szkole mądrości. Tym samym zdobywa umiejętność wspierania męża w jego troskach o dom rodzinny. Dzieli jego troski, zdobywa umiejętność wypełniania obowiązku bycia jego doradczynią ${ }^{17}$.

Kierowanie domem jest według Złotoustego nie tylko przywilejem, ale sztuką nad sztukami ${ }^{18}$. Sporo miejsca kaznodzieja antiocheński poświęca obowiązkowi wychowania dzieci. Ojciec, obdarzony władzą nauczyciela, jest powołany do tego, by ciągle formować siebie i stawać się coraz doskonalszym głównym nauczycielem całego środowiska rodzinnego ${ }^{19}$.

Mężowie są ustanowieni, aby kierować małżonkami nie dlatego, żeby panować i korzystać z przywileju bycia głową, ale dlatego, żeby troszczyć się i wyprzedzać wszystkich domowników w zdobywaniu cnoty. Kiedy inni domownicy, zwłaszcza żona, wyprzedzi męża zdobywaniem cnót, przestaje on być głową ogniska rodzinnego ${ }^{20}$.

W przekonaniu Chryzostoma „cnoty podnoszą wszystkich do tej dziwnej pierwotnej piękności, którą wyróżniał się człowiek, kiedy został stworzony na obraz i podobieństwo Boże"21.

Mąż ze wszystkich sił powinien uczynkami, a nie słowami dążyć do zdobycia cnót we własnym domu. Natomiast jego pomocnica, żona, nade wszystko powinna troszczyć się, żeby wszyscy członkowie podejmowali trud dla osiągnięcia królestwa niebieskiego ${ }^{22}$. Pan Bóg dał człowiekowi ręce i nogi, obdarzył go rozumem, zdrowiem fizycznym, sympatią, darem mowy, żeby tym wszystkim mógł posługiwać się dla własnego dobra oraz dobra bliźnich, przede wszystkim w trosce o zbawienie dusz ${ }^{23}$.

17 Por. О. Паскуато, Миряни у Йоана Золотоустого..., dz. cyt., s. 62, 64, 130-131.

18 Por. Joannes Chrysostomus, Eloga de Mulieribus et Pulchritudine, 14, PG 63, 661-662; Выборки из разных слов. Слово XIV. О женщинах и о красоте, t. ХІІ/1, s. 600; Св. Й. Золотоустий, Зібрання повчань, Сz. 1, s. 287.

19 Por. О. Паскуато, Миряни у Йоана Золотоустого..., dz. cyt., s. 130-132; św. J. Chryzostom, 0 małżeństwie, wychowaniu dzieci i ascezie, przekł. W. Kania i in., red. J. Naumowicz, J. Krykowski, Kraków 2002, s. 29.

20 Por. О. Паскуато, Миряни у Йоана золотоустого..., dz. суt., s. 62-63.

${ }_{21}$ Перлини Східних Отц̧ів, ред. Ю. Катрій, Львів 20063, s. 336; zob. również podobne teksty: Joannes Chrysostomus, Homilia in Matthœum, 11, 3, PG 57, 195-196, Толкование на святого Матфея евангелиста. Беседа XI, 11, 3, t. VII, s. 124; Homilia in Mattheum, 57, 5, PG 58, 555-556; Толкование на святого Матфея евангелиста. Беседа LXVII, 5, t. VII, s. 609-611.

22 Por. Ecloga 2. De Oraione, PG 63, 581; Повчання про молитву і духовну тверезість, [w:] Святі Отиі. Про молитву та духовну тверезість, пер. М. Лемик, Львів 2007, s. 79.

${ }_{23}$ Por. Joannes Chrysostomus, Homilia in Matthœum, 78, 3, PG 58, 705-706; Толкование на святого Матфея евангелиста. Беседа LXXVIII, t. VII, s. 814. 
Życie według przykazań Bożych przynosi samosatysfakcję oraz wielką korzyść dla domowników. Prowadząc uczciwe życie, uwielbią Boga wszechmogącego - najpierw mąż, a potem całe środowisko rodzinne ${ }^{24}$.

\section{Wyrozumiałość względem żony}

W relacjach małżeńskich mążi żona powinni praktykować samozaparcie oraz całkowite ofiarowanie się jedno drugiemu. Tym samym naśladują Chrystusa Pana oraz ofiarowują sobie nawzajem najwierniejszą sympatię i miłośćc5.

Antiocheńczyk stawia przed mężami wymagania dotyczące postępowania wobec żon: dawać im wszystko, czego zapragną, być wyrozumiałym, cierpliwym $^{26}$. Kaznodzieja zachęca mężów, żeby nie bali się kochać żon, jednocześnie przestrzega, żeby nie chlubili się pokorą małżonek. Jednocześnie miłość męża nie powinna stać się okazją do zuchwalstwa ze strony żony ${ }^{27}$. Aby żona korzyła się przed mężem jak przed Panem, powinien on troszczyć się o nią jak Chrystus opiekuje się Kościołem² ${ }^{28}$; bez narzekań przyjmować narzekania, cierpienia, bóle, niebezpieczeństwa i znosząc to wszystko, być gotowym nawet oddać życie za rodzinę. Nie istnieje nic mocniejszego od przymierza pomiędzy mężczyzną i kobietą wyrażającego się w sakramencie małżeństwa ${ }^{29}$.

Mąż, będąc głową, własnym przykładem życia uczy żonę - własne ciało: łagodności, cnotliwości oraz umiarkowania w relacji do zasobów materialnych. Z wielkim szacunkiem do płci kobiecej, która według niego jest słabsza od męskiej, zachęca Jan Chryzostom, żeby mąż ukazywał żonie, iż praw-

24 Por. Joannes Chrysostomus, Homilia in Joannem 57, 3, PG 59, 310; Беседа LVII на Иоанна IX, 6-7, t. VIII, s. 390.

25 Por. О. Паскуато, Миряни у Йоана Золотоустого..., dz. суt., s. 100-101.

26 Joannes Chrysostomus, In epistulam ad Ephesios, 20, 4, PG 62, 139-141; Беседа XX на Эфеc., 20, 4, t. XI, s. 177-179.

27 Por. Joannes Chrysostomus, In epistulam ad Collosenses, 10, 1, PG 62, 365-366; Беседа X на Колосс. III, 18-25, t. XI, s. 453-454.

${ }_{28}$ Por. Joannes Chrysostomus, In epistulam ad Ephesios, 20, 2-4, PG 62, 136-141; Беседа XX на Эфес., 20, 2-4, t. XI, s. 45-50; G. Fregni, Miłujcie się czule..., dz. cyt., s. 36.

${ }_{29}$ Por. C. Scaglioni, Ideale coniugale e familiare in San Giovanni Crisostomo, [w:] Etica sessuale e matrimonio nel cristianesimo delle origini, a cura di R. Cantalamessa, Milano 1976, s. 355; О. Паскуато, Миряни у Йоана Золотоустого..., dz. суt., s. 100-101. 
dziwą ozdobą jest skromność i prawda, że bieda nie jest złem, a wielkim niebezpieczeństwem jest bogactwo oraz miłość do pieniędzy. Lekarstwem jest wstydliwość męża przed Bogiem i żoną. Wstydliwy, czyli cnotliwy mąż przynosi do domu harmonię oraz poczucie bezpieczeństwa dla wszystkich domowników ${ }^{30}$. Żonę trzeba szanować, chwalić, poświęcać jej sporo uwagi, zachwycać się nią, uczyć, czego potrzeba, w domu jej oddawać przewagę. Wtedy dla żony nie będą istnieć żadne pokusy, inni mężczyźni nie będą mieć dla niej żadnego znaczenia ${ }^{31}$.

Po zawarciu małżeństwa mąż i żona nie mają więcej osobnej własności, a tylko wpólną. Nie mając władzy nad własnym ciałem, tym bardziej mąż - głowa rodziny, nie ma władzy nad tym wszystkim, co do niego wcześniej należało ${ }^{32}$. Mężczyzna, który uważa, iż małżeństwo może być źródłem zysku, i dlatego żeni się z bogatą dziewczyną, bierze sobie zamiast pomocnicy władczynię, która zniewalając go, czyni z niego niewolnika ${ }^{33}$. Chęć zysku według Złotoustego przysparza wiele kłopotów ${ }^{34}$. Bogata oraz apodyktyczna małżonka często zajmuje miejsce głowy i upokarzając męża, narusza porządek ustanowiony przez Boga Swórcę ${ }^{35}$.

Nawet w wypadku braku miłości męża do żony i żony do męża należy zachwywać wierność Bogu i jego przykazaniom ${ }^{36}$. Nie dlatego Pan Bóg nakazał mężczyźnie opuścić rodziców, żeby krzywdzić małżonkę. Przemoc względem żony Chryzostom mocno piętnuje ${ }^{37}$.

30 Por. Joannes Chrysostomus, In epistulam ad Ephesios, 20, 1-4, PG 62, 135-141; Беседa XX на Эфес., 20, 1-4, t. XI, s. 172-179.

31 Por. Joannes Chrysostomus, In epistulam ad Ephesios, 20, 2-4, PG 62, 135-141; Беседa XX на Эфес., 20, 1-4, t. XI, s. 172-179.

32 Por. Joannes Chrysostomus, In Epistolam I ad Corinthios, 19, 1, PG 61, 151-152; Беседа XIX на 1 Kop. VII, 1-2, t. X, s. 184.

33 Por. Św. J. Chryzostom, o małżeństwie, dz. cyt., s. 20.

34 Por. Joannes Chrysostomus, In epistulam ad Ephesios, 20, 2-4, PG 62, 136-141; Беседa XX на ЭФес., 20, 2-4, t. XI, s. 174-179.

35 Por. Joannes Chrysostomus, De Virginitate liber unus, 53, PG 48, 576, Книга о девстве, t. I, s. 449; Joannes Chrysostomus, Laus Maximi, et quales ducendae sint uxores, 4, PG 51, 230-231; III Похвала Максиму, и о том, каких должно брать жен, t. III, s. 245.

36 Por. Joannes Chrysostomus, In epistulam ad Ephesios, 20, 2-4, PG 62, 136-141; Беседа XX на Эфес., 20, 2-4, t. XI, s. 174-179.

37 Por. Joannes Chrysostomus, De Eleemosyna Sermo, 4, PG 51, 266-267; Беседа о милостыне, произнесенная после того как он (св. Златоуст) в зимнее время прошел и увидел на площади 
Kłótnia i wrogość w domu rodzinnym rozszerza się na całe społeczeństwo. Dla małżonków, którzy są pozbawieni wyrozumiałości oraz harmonii, dobrobyt, bogactwo, rozkosze, władza nie przynoszą żadnego pożytku. Dzięki harmonii oraz wzajemnej pomocy pomiędzy małżonkami rodzi się wiele dobra. Dlatego w swych homiliach Jan Chryzostom niemalże błaga, żeby mąż był dla żony największym skarbem oraz żeby dla męża żona była jak najbardziej pożądaną osobą ${ }^{38}$.

Żeby zdobyć uznanie przed Bogiem oraz wzmocnić miłość i przychylność u męża, żona ozdabia siebie skromnością, łagodnością, pokorną cierpliwością, miłością i szacunkiem dla męża. Inne ozdoby, zwłaszcza te zrobione z drogocennych kamieni, nie przynoszą radości, czynią to tylko te duchowe, niezbędne w codziennych trudach i zmaganiach całej rodziny, na której czele stoi Jezus Chrystus. Cnota na ziemi czyni małżonków bezpiecznymi, bo wiedzie do nieba ${ }^{39}$.

Za przykład prawdziwej kobiecości Złotousty stawia biblijne postacie kobiet: Sarę, Rebekę oraz Liję. Według niego były one pełne przyrodzonego oraz duchowego piękna ${ }^{40}$.

Sporo miejsca poświęca on także modlitwie, ponieważ przy jej pomocy człowiek potrafi jak najlepiej pomóc sobie oraz bliźniemu w zdobywaniu cnoty i otrzymaniu nagrody od Boga. Mąż pomaga żonie, troszczy się o jej duszę nie dlatego, żeby ona podobała się tylko jemu samemu, ale przede wszystkim Bogu ${ }^{41}$. Wszystko, co się znajduje w ciele, przeznaczone jest do służenia. Złotousty nawet radzi mężom, żeby stawiali oni żonom więcej wymagań niż te, które one same sobie postawiły.

Żona jest ciałem męża, dlatego zasługuje na szególną miłość z jego strony. Żadne wykroczenie, żadna wada, nic nie powinno naruszyć tej miło-

бедных и нищих, лежкщщих без призрения, 4, t. III, s. 286-288.

38 Por. Joannes Chrysostomus, Non oportare quemquam de seipso desperare, aut preces contra inimicos fundere aut animo deficere, quamvis petens non accipiat; et ad maritos de pace arga uxores conseveranda, 6-7, PG 51, 569-570; Беседа О том, что никому не должно отчаиваться, ни молиться о вреде врагам, ни падать духом, не получая просимого; также к мужьям о сохранении мира сженами, t. III, s. 403.

39 Por. О. Паскуато, Миряни у Йоана Золотоустого..., dz. суt., s. 88-89.

40 Por. Joannes Chrysostomus, Homilia in Mattheum, 30, 3, PG 57, 361-362; Толкование на святого Матфея евангелиста. Беседа ХХХ, 30, 3, t.VII, s. 350.

${ }^{41}$ Por. Joannes Chrysostomus, In epistulam ad Ephesios, 20, 2-4, PG 62, 136-141; Беседа XX на Эфес., 20, 2-4, t. XI, s. 174-179. 
ści ${ }^{42}$. Tylko miłość stanowi główną wartość sakramentu małżeństwa ${ }^{43}$. Jak Chrystus kocha Kośćiół i go oczyszcza, tak samo i mąż, kiedy jest pełen miłości Chrystusowej, czyni podobnie wobec żony ${ }^{44}$.

Nawet wtedy, kiedy żona różni się od swego męża, nie jest aż na tyle różna od niego, ponieważ Kościół nie różni się zbytnio od Zbawiciela. Jest Jego Ciałem Mistycznym ${ }^{45}$. $Z$ tej to przyczyny nie trzeba dokuczać żonie albo wymagać od niej za wiele. Prawdziwy mąż jest wyrozumiały i świeci przykładem miłosierdzia względem niej ${ }^{46}$.

Życie zgodne z wolą Boga jest główną treścią XX homilii Jana Chryzostoma do Listu do Efezjan ${ }^{47}$. Małżeńtwo, które bardzo boi się Boga, czyli mające w codziennym życiu prawdziwą bojaźń, otrzyma od Niego wielką nagrodę i uznanie. A szukając przede wszystkim dóbr duchowych, czyli wiecznych, otrzyma i te, które są potrzebne w życiu doczesnym ${ }^{48}$.

\section{3. „Domus enim est parva Ecclesia”49}

Kiedy mężowie, których głową jest sam Jezus Chrystus, wyposażeni w potrzebne zalety są zdolni kierować własnymi domami, wtedy ich ognisko rodzinne staje się, według nauczania Jana Chryzostoma, „,małym Kościołem ${ }^{50}$.

42 Por. Joannes Chrysostomus, Laus Maximi, et quales ducendae sint uxores, 2-3, PG 51, 226-227, 229-230; ІІІ Похвала Максиму, и о том, каких должно брать жен, t. III, s. 240, 242.

43 Por. О. Паскуато, Миряни у Йоана золотоустого..., dz. суt., s. 101.

44 Por. Joannes Chrysostomus, Laus Maximi, et quales ducendae sint uxores, 2-3, PG 51, 226-230; III Похвала Максиму, и о том, каких должно брать жен, t. III, s. 240-242.

45 Por. G. Fregni, Miłujcie się czule..., dz. cyt., s. 37.

46 Por. Joannes Chrysostomus, In epistulam ad Ephesios, 20, 2-4, PG 62, 136-141; Беседa XX на Эфес., 20, 2-4, t. XI, s. 174-179; Homilia in Matthœum, 30, 2-3, PG 57, 359-360; Толкование на святого Матфея евангелиста. Беседа XXX, t.VII, s. 348-349; G. Fregni, Miłujcie się czule..., dz. cyt., s. 35-36.

47 Por. О. Паскуато, Миряни у Йоана золотоустого..., dz. cyt., s. 63.

48 Por. Joannes Chrysostomus, In epistulam ad Ephesios, 20, 2-4, PG 62, 136-141; Беседа XX на Эфес., 20, 2-4, t. XI, s. 174-179.

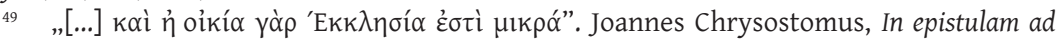
Ephesios, 20, 6, PG 62, 143.

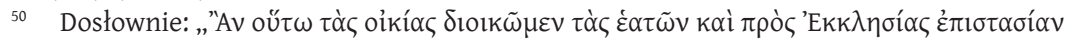

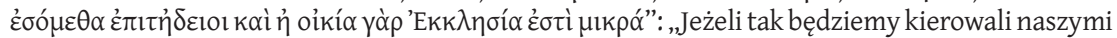
domami, będziemy zdolni kierować i Kościołem, ponieważ dom to mały Kościół [parva Ecclesia]”. 
Ten warunek postawiony głowie rodziny jest konieczny, żeby można było określić rodzinne ognisko terminem parva Ecclesia. Mąż jest powołany do tego, by godnie i uczciwie zarządzać domem oraz jego mieszkańcami. Sam Stwórca zechciał, żeby mąż kierował domem w całości ${ }^{51}$. Z tej to przyczyny w pierwszych wiekach chrześcijaństwa przekonywano heretyków, iż małżeństwo jest uczciwym związkiem mężczyzny i kobiety.

Należyta troska o rodzinę, zwłaszcza o żonę i dzieci, przysposabia bowiem męża do postawy bycia odpowiedzialnym za nich przed Bogiem Ojcem ${ }^{52}$. Skoro mąż jest dobry i mądry, w jego domu nie będzie bałaganu. A ten, kto potrafi zaprowadzać harmonijne relacje wśród domowników, jest zdolny kierować nawet wspólnotą wiernych (czyli Kościołem), ponieważ dom to parva Ecclesia. Ten, kto dobrze ułożył sprawy materialne, dobrze ułoży i duchowe ${ }^{53}$.

Małżonkowie jako członkowie Kościoła bezpośrednio uczestniczą w relacjach Chrystus-Kościół. Jak w Kościele, tak i w rodzinie istnieje ustrój hierarchiczny. Mąż jest głową rodziny. Wynika to z obrazu Ciała Mistycznego, którego Głową jest Chrystus (zob. Ef 5, 22-24), a jego powołanie do bycia nauczycielem pochodzi z urzędu biskupa, prawdziwego ojca wspólnoty wiernych ${ }^{54}$. Prawdziwy zarządca domu cnotą pokory oraz harmonią zachęca domowników do współudziału w trosce o zbawienie dusz ${ }^{55}$.

Joannes Chrysostomus, In epistulam ad Ephesios, 20, 6, PG 62, 143; Беседа XX на Эфес., 20, 6, t. XI, s. 182. О. Паскуато, Миряни у Йоана Золотоустого..., dz. cyt., s. 105; W innej homilii Złotousty mówi, jak należy traktować sprawę kierowania domem: „Kościół - to samo, co mały dom. I tak, jak w domu są dzieci, kobiety, służba, a przede wszystkim jego ludzie, nad nimi władzą wywyższa się mąż. Podobnie i w Kościele nie bywa inaczej, ponieważ są w nim: dzieci, kobiety oraz słudzy. Jeśli głowa Kościoła ma wspólników swojej władzy, to i tam mąż posiada własną wspólniczkę, żonę. Czy i tutaj trzeba zatroszczyć się o pokarm dla wdów i dziewic. I tam też mąż ma w opiece córki niewolników. Zresztą domem kierować jest łatwiej. Więc jak może zarządzać sprawami Kościoła ten, kto o własny dom nie zadbał prawidłowo?". Joannes Chrysostomus, In epistulam I ad Timotheum, 10, 2, PG 62, 549, Беседа Х на 1 Tим. III, 1-4, 10, 2, t. XI, s. 707.

51 Por. О. Паскуато, Миряни у Йоана Золотоустого..., dz. суt., s. 106, 130-131.

52 Por. Joannes Chrysostomus, In epistulam ad Ephesios, 20, 6, PG 62, 143; Беседа XX на $\exists \oint e c ., 20,6$, t. XI, s. 182.

53 Por. Joannes Chrysostomus, In epistulam ad Titum, 4, 2, PG 62, 683-684; Беседа IV на Tum. II, 2-5, t. XI, s. 891.

${ }_{54}$ Por. św. J. Chryzostom, O małżeństwie..., dz. cyt., s. 30; G. Fregni, Miłujcie się czule..., dz. cyt., s. 46.

55 Рor. О. Паскуато, Миряни у Йоана Золотоустого..., dz. cyt., s. 133; Ojcowie żywi. Karmię Was tym, czym sam żyję. Komentarze na Ewangelie rok C, red. M. Starowieyski, t. III, Kraków 1980, s. 127. 
Tak jak duchowni będą odpowiadać przed Bogiem za zbawienie dusz powierzonych im wiernych, tak głowa rodziny odpowie przed Stworzycielem życia za wszystkich domowników, jakimi zarządza na ziemi ${ }^{56}$.

Dlatego według porad kaznodziei z Antiochii głowa rodziny nie będzie troszczyć się o dobra materialne, w tym o pieniądze, ale zwłaszcza o to, żeby przedstawić Bogu dusze tych, których On mu powierzył w doczesności.

Żona może być pomocna mężowi w sprawie zbawienia duszy, jeżeli będzie przykładem skromności, łagodności, cierpliwości, jeżeli nie będzie zbytnio przywiązana do pieniędzy oraz rzeczy materialnych, będzie wspierać małżonka i za nic będzie mieć życie ziemskie, a nade wszystko będzie potrafiła żyć zgodnie z nauką Pisma Świętego, ukazując swą cierpliwością życiową mądrość. Związek małżeński jest dla męża szkołą świętości i zdobycia doskonałości, środkiem zbawienia wszystkich członków rodziny ${ }^{57}$. Dlatego mąż, który został biskupem w Kościele, jest powołany z urzędu do bycia przykładem życiowej mądrości, żywym przymierzem, do uosabiania łagodności, do gorliwego uczenia się tekstów Pisma Świętego ${ }^{58}$.

Mąż spełnia rolę nauczyciela dla żony ${ }^{59}$. Żona nie może nauczać w Kościele, jednak może być nauczycielką w parva Ecclessia. Kobieta w podeszłym wieku powinna nauczać i być przykładem dla kobiet młodszych od siebie. Według Złotoustego nie chodzi tu o córki, ale o inne młodsze od niej kobiety ${ }^{60}$. Mąż, który w domu przekazuje zbawcze treści, przykazania Pańskie, o których słyszał w kościele, proroctwa proroków oraz nauczanie apostołów, tym samym żonę czyni cnotliwszą, syna mądrzejszym, przyjaciela bardziej otwartym, a sługę bardziej wiernym; ponieważ proponuje im wszystkim ucztę przepełnioną cnotami ${ }^{61}$. Parva Ecclesia oprócz żywności materialnej karmi

\footnotetext{
56 Por. G. Fregni, Miłujcie się czule..., dz. cyt., s. 46.

${ }_{57}$ Por. Św. J. Chryzostom, O małżeństwie..., dz. cyt., s. 28; G. Fregni, Miłujcie się czule..., dz. cyt., s. 46.

58 Por. Joannes Chrysostomus, In epistulam I ad Timotheum, 9, 1-2, PG 62, 543-548; Беседа IX на 1 Tим. II, 11-15, t. XI, s. 699-704; О. Паскуато, Миряни у Йоана Золотоустого..., dz. cyt., s. 131; św. J. Chryzostom, O małżeństwie..., dz. cyt., s. 32.

59 Por. О. Паскуато, Миряни у Йоана Золотоустого..., dz. суt., s. 132.

60 Por. Joannes Chrysostomus, In epistulam ad Titum, 4, 2, PG 62, 683; Беседа IV на Tum. II, 2-5, t. XI, s. 890 .

${ }_{61}$ Por. Joannes Chrysostomus, De Paenitentia, 6, 1, PG 49, 313; Беседы о покаянии. Беседа VI, t. II, s. 362.
} 
się w domu słowem Bożym² ${ }^{62}$ Po takiej podwójnej uczcie dom napełnia się atmosferą radości. Nawet sen jest bardziej zrównoważony, pełen pięknych i przyjemnych widoków ${ }^{63}$.

Lekturze Pisma Świętego towarzyszy modlitwa, czyli wspólne śpiewanie psalmów za stołem rodzinnym po spożyciu posiłku. W ten sposób dom przemienia się w kościół, do którego złe duchy nie śmią zaglądnąć. Modlitwa to najlepszy środek przeciwko wszystkim namiętnościom, nieumiarkowaniu, zwłaszcza w piciu wina ${ }^{64}$. Modlitwa pomaga powstrzymać język od gadulstwa. Wiele razy Chryzostom zachęcał, by w codziennej pracy było dużo modlitwy i śpiewu psalmów oraz pieśni pobożnych. Radzi nie przestawać wielbić Boga także w nocy oraz w modlitwach żarliwie błagać Go i wypraszać potrzebne łaski ${ }^{65}$. Noc nie jest stworzona tylko dla ciała. W nocy nikt człowieka nie odwodzi od modlitwy. Ten czas jest dany na modlitwę, ponieważ wtedy umysł człowieka jest spokojniejszy, wolny od trosk, panuje w nim cisza. Ojciec Kościoła podkreśla, jak wielkim brakiem rozsądku oraz niewdzięcznością jest poświęcanie pięciu czy sześciu dni na troski doczesne, a tylko siódmego dnia czy tylko jednej jego części na sprawy duchowe ${ }^{66}$. Pan Bóg mógł podzielić ten czas równomiernie albo zarezerwować sobie większą liczbę dni. Tego, kto „wykrada” ten uświęcony przez Pana Boga dzień, Chryzostom nazywa „świętokradcą" ${ }^{67}$.

${ }^{62}$ Według Chryzostoma istnieje reguła: „Zachowajmy treści i wróciwszy do domu, zastawmy dwa stoły: stół pokarmów i stół wykładu... Niech mąż przedstawi to, co zostało powiedziane, a żona niech się uczy, niech słuchają także dzieci, i nawet niewolnicy niech nie będą pozbawieni tego wykładu". Joannes Chrysostomus, In Genesim, Sermo 6, 2, PG, 54, 607; tłum. polskie: Homilie na Księge Rodzaju (seria pierwsza: Rdz 1-3), red. i tłum. S. Kaczmarek, Kraków 2008, s. 95 (Źródła Myśli Teologicznej, 45); por. również tłum. rosyjskie: Восемь слов на книгу Бытия, Слово VI, t. IV, s. 781.

${ }_{63}$ Por. О. Паскуато, Миряни у Йоана Золотоустого..., dz. cyt., s. 77-78, 146-147.

64 Por. św. J. Chryzostom, 0 małżeństwie..., dz. cyt., s. 31.

65 Por. О. Паскуато, Миряни у Йоана Золотоустого..., dz. суt., s. 77-78, 107.

${ }_{66}$ Por. G. Fregni, Miłujcie się czule..., dz. cyt., s. 53.

67 Por. Joannes Chrysostomus, De baptizmo Christi, 4, PG 49, 372; 24. Умовляння приходити до изеркви. Слово про хрещення, [w:] Зібрання повчань, сz. 1, ред. І. Жеребецька, Жовква 2010², s. 52: „Gdy spożyjesz zwykły pokarm, wstawszy od stołu odmawiasz modlitwę, a gdy ci dano pokarm duchowy, który o wiele przewyższa wszelkie widzialne i niezwykłe stworzenie, choć jesteś człowiekiem, czyli słabą istotą, nie chcesz słowem i czynem złożyć dziękczynienia". Tymi słowami Antiocheńczyk zwraca też uwagę na usposobienie duchowe oraz zachowanie tych, którzy mają przyjąć Komunię Świętą. 
W czasach Jana Chryzostoma nie istniał teatr chrześcijański, tylko pogański. Złotousty mówił, że do udziału w nim skłania mężczyz napięta sytuacja w domu. W teatrach odgrywano sceny miłosne, dlatego Chryzostom nazywał widowiska „szkołą bałaganu”68. Zachęcał do chodzenia do kościoła, a nie do teatru, ponieważ uczestnictwo w liturgii, spędzenie czasu w świątyni nie jest daremne, lecz przynosi sporo zysku ${ }^{69}$.

W innym miejscu przekonywał o korzyści wynikającej z modlitwy wtedy, kiedy jest praktykowana wspólnie i zanoszona do Boga razem z kapłanami. Człowiek czerpie korzyść z modlitwy, ponieważ jest ona matką mądrości. Dlatego radził mężczyznom ciągle trwać w modlitwie, zwłaszcza rano, przed spaniem, oraz kiedy przychodzi noc, pozostawać na czuwaniu. Modlitwa pomaga godnie przeżyć życie ziemskie, ratuje od biedy, przyszłych cierpień, pomaga osiągnąć życie wieczne ${ }^{70}$.

$* * *$

Podsumowując poglądy Jana Chryzostoma na temat roli mężczyzny jako ojca rodziny, warto zauważyć, iż wielki kaznodzieja antiocheński faworyzuje mężczyzn. Ich obowiązki rodzinne wywodzą się z bojaźni wobec Boga i szacunku do żony - równej w porządku godności oraz innej w porządku spełniania obowiązków. Zadziwia jego głęboki szacunek do płci żeńskiej. XX homilia do Listu do Efezjan to wzorcowa lektura dla małżonków, w której zarówno mąż, jak i żona mogą odnaleźć wiele cennych wskazówek.

68 Por. św. J. Chryzostom, O małżeństwie..., dz. cyt., s. 22.

69 Por. Joannes Chrysostomus, De Paenitentia, 6, 2, PG 49, 314; Беседы о покаянии. Беседа VI, t. II, s. 363.

70 Пор. Joannes Chrysostomus, Homilia in Matthœum, 19, 2, PG 57, 275-276; Толкование на святого Матфея евангелиста. Беседа XIX, t. VII, s. 226-228; Homilia in Matthœuт, 23, 5, PG 57, 305-306; Толкование насвятого Матфея евангелиста. Беседа XXIII, s. 276; Spuria. De oratione, PG 62,737-740; Выборки из разных слов. Слово II. О молитве, t. XII/1, s. 497-498, 500-501, 505. 


\section{Summary}

The role of father according to the st. John's Chrysostom 20 th Homily on Ephesians

The division of family responsibilities, which are designed for each household member and harmonious family relationships are one of the most important keynotes of St. John's Chrysostom preaching. In order to explain this issue he wrote homily on the Epistle to the Ephesians. According to it, the role of father in household is based on following Christ. Husbant's relationship to his wife, especially respect for her, should be built by analogy to the relationship between Christ and the Church. The author calls the family a "small church", comparing it to the Church as the Mystical Body. Living of the "small Church" is permeated with prayer and Holy Scripture reading. Firstly husband - the head of the family, performs the following Christian actions: reads inspired texts, strengthens himself by the sacrament of the Eucharist (that is, he takes the Holy Communion). And thanks to that going to church and celebrate the Lord's Day, are the usual practice of all members of the parva Ecclesia.

Keywords: father, family, husband, wife, small Church

\section{Rola ojca na podstawie XX homilii św. Jana Złotoustego do Listu do Efezjan}

Podział obowiązków rodzinnych, które są wyznaczone dla każdego członka rodziny, oraz harmonijne relacje rodzinne są kwestiami kluczowymi w myśli Jana Chryzostoma. Temu zagadnieniu poświęcił on homilie do Listu do Efezjan. Rola ojca w rodzinie wypływa z naśladowania Chrystusa. Jego relacja do żony, zwłaszcza szacunek dla niej, ma być budowana na relacjach Chrystusa do Kościoła. Nazywa rodzinę małym Kościołem, porównując ją do Kościoła jako Ciała Mistycznego. Życie „małego Kościoła” jest przeniknięte modlitwą oraz czytaniem Pisma Świętego. Najpierw mąż - głowa rodziny, wykonuje następujące praktyki chrześcijańskie: czyta teksty natchnione, czerpie siłę z sakramentu Eucharystii (czyli przystępuje do Komunii Świętej). Chodzenie do kościoła oraz świętowanie Dnia Pańskiego pozostają zwykłą praktyką wszystkich członków parva Ecclesia.

Słowa kluczowe: ojciec, rodzina, mąż, żona, mały Kościół

\section{Bibliografia}

Fregni G., Miłujcie sięczule. Duchowość rodziny według Ojców Kościoła, tłum. D. Wandzioch, Kraków 2002.

In Genesim, Sermo 6, 1-2, Patrologia Graeca, 54, 604-607; tłum. polskie: Homilie na Ksiege Rodzaju (seria pierwsza: Rdz 1-3), red. i tłum. S. Kaczmarek, Kraków 2008, s. 91-95 (Źródła Myśli Teologicznej, 45); Восемь слов на книгу Бытия, Слово VI, 6, 1-2, t. IV, s. 778-781. 
In librum ad eos qui scandalizati sunt ob adversitates, 22. [XX. Afflictiones non modo non scandalizzare, sed et prodesse illis qui ex aequo et bono judicent], Patrologia Graeca 52, 523524; Joannes Chrysostomus, Беседа О том, что никому не должно отчаиваться, ни молиться о вреде врагам, ни падать духом, не получая просимого; также к мужьям о сохранении мира с женами, 22, t. III, s. 403-404.

Joannes Chrysostomus 24. Умовляння приходити до церкви. Слово про хрещення, [w:] Зібрання повчань, сz. 1, ред. І. Жеребецька, Жовква 2010², s. 51-53.

Joannes Chrysostomus, De baptizmo Christi, 4, Patrologia Graeca 49, 363-372.

Joannes Chrysostomus, De Eleemosyna Sermo, 1-6, Patrologia Graeca 51, 261-272; Беседa о милостыне, произнесенная после того как он (св. Златоуст) в зимнее время прошел и увидел на площзади бедных и нищзих, лежащзих без призрения, 1-6, Почаев, t. III, s. 279-292.

Joannes Chrysostomus, De Paenitentia, 6, 1-5, Patrologia Graeca 49, 313-324; Беседы о покаянии. Беседа VI, 1-5, t. II, s. 360--372.

Joannes Chrysostomus, De Virginitate liber unus, 1-84, 53, Patrologia Graeca 48, 533596, Книга о девстве, 1-84, t. I, s. 397-472.

Joannes Chrysostomus, Ecloga 2. De Oraione, Patrologia Graeca 63, 579-590; Повчання про молитву і духовну тверезість, [w:] Святі Отизі. Про молитву та духовну тверезість, пер. М. Лемик, Львів 2007, s. 50-113.

Joannes Chrysostomus, Ecloga 7. De humilitate animi, Patrologia Graeca 63, 615-622; Слово VII. О смиренномудрии, т. XII/1, s. 542-548.

Joannes Chrysostomus, Eloga de Mulieribus et Pulchritudine, Homilia XIV, Patrologia Graeca 63, 657-666; Выборки из разных слов. Слово XIV. О женщзинах и о красоте, t. XII/1, s. 595-607.

Joannes Chrysostomus, Homilia in Ioannem 57, 1-3, Patrologia Graeca 59, 313-322; Беседа LVII на Иоанна IX, 6-7, 1-3, t. VIII, s. 384-390.

Joannes Chrysostomus, Homilia in Matthoum, 11, 1-8, Patrologia Graeca 57, 191-202, Толкование на святого Матфея евангелиста. Беседа XI, 1-8, t. VII, s. 113-126.

Joannes Chrysostomus, Homilia in Matthoum, 19, 1-8, Patrologia Graeca 57, 273-286; Толкование на святого Матфея евангелиста. Беседа ХIX, 1-8, t. VII, s. 222-239.

Joannes Chrysostomus, Homilia in Matthœum, 23, 1-10, Patrologia Graeca 57, 299-308; Толкование на святого Матфея евангелиста. Беседа ХХІІІ, 1-10, s. 267-285.

Joannes Chrysostomus, Homilia in Matthoeum, 30, 1-6, Patrologia Graeca 57, 357-362; Толкование на святого Матфея евангелиста. Беседа ХХХ, 1-6, t.VII, s. 340-351.

Joannes Chrysostomus, Homilia in Matthoum, 57, 1-5, Patrologia Graeca 58, 549-558; Толкование на святого Матфея евангелиста. Беседа LXVII, 1-5, t. VII, s. 601-611.

Joannes Chrysostomus, Homilia in Matthoum, 78, 1-4, Patrologia Graeca 58, 701-710; Толкование на святого Матфея евангелиста. Беседа LXXVIII, 1-4, t.VII, s. 809-817.

Joannes Chrysostomus, In Epistolam I ad Corinthios, 19, 1-6, Patrologia Graeca 61, 151160; Беседа XIX на 1 Кор. VII, 1-2, 1-6, t. X, s. 183-194.

Joannes Chrysostomus, In epistulam ad Collosenses, 10, 1-5, Patrologia Graeca 62, 365374; Беседа Х на Колосс. III, 18-25, 1-5, t. XI, s. 453-462.

Joannes Chrysostomus, In epistulam ad Ephesios, 20, 1-9, Patrologia Graeca, 62, 135150; Беседа ХХ на Эфес., 20, 1-9, t. XI, s. 172-190. 
Joannes Chrysostomus, In epistulam ad Titum, 4, 1-5, Patrologia Graeca 62, 681-689; Беседа IV на Tum. II, 2-5, 1-5, t. XI, s. 889-897.

Joannes Chrysostomus, In epistulam I ad Corinthios, 34, 1-7, Patrologia Graeca 61, 285296; Беседа XXXIV на 1 Кор. XIII, 13, 1-7, t. X, s. 354-366.

Joannes Chrysostomus, In epistulam I ad Timotheum, 10, 1-3, Patrologia Graeca 62, 547564, Беседа X на 1 Тим. III, 1-4, 10, 1-3, t. XI, s. 704-712.

Joannes Chrysostomus, In epistulam I ad Timotheum, 9, 1-2, Patrologia Graeca 62, 543548; Беседа IX на 1 Тим. II, 11-15, 9, 1-2, t. XI, s. 699-704.

Joannes Chrysostomus, Laus Maximi, et quales ducendae sint uxores, 1-9, Patrologia Graeca 51, 225-242; III Похвала Максиму, и о том, каких должно брать жен, 1-9, t. III, s. 237-257.

Joannes Chrysostomus, Monitum. Ad viduam iuniorem, 1-7, Patrologia Graeca 48, 599610, IX. К молодой вдове. Слово второе о воздержании от второго брака, 1-6, t. I, s. 485-496.

Joannes Chrysostomus, Non oportare quemquam de seipso desperare, aut preces contra inimicos fundere aut animo deficere, quamvis petens non accipiat; et ad maritos de pace arga uxores conseveranda, 1-7, Patrologia Graeca 51, 363-373; Беседа О том, что никому не должно отчаиваться, ни молиться о вреде врагам, ни падать духом, не получая просимого; также к мужьям о сохранении мира с женами, 1-7, t. III, s. 397-405.

Joannes Chrysostomus, Spuria. De oratione, Patrologia Graeca 62, 737-740; Выборки из разных слов. Слово II. О молитве, t. XII/1, s. 497-510.

Joannes Chrysostomus, Spuria. Sermo de caritate, Patrologia Graeca 60, 773-776; Выборки из разных слов. Беседа I. О любви, t. ХІІ/1, s. 483-497.

Ojcowie żywi. Karmię Was tym, czym sam żyję. Komentarze na Ewangelie rok $C$, red. M. Starowieyski, t. III, Kraków 1980.

Scaglioni C., Ideale coniugale e familiare in San Giovanni Crisostomo, [w:] Etica sessuale e matrimonio nel cristianesimo delle origini, a cura di R. Cantalamessa, Milano 1976, s. 273-422.

Szczur P., Ideał doskonałościchrześcijańskiej według Jana Chryzostoma, „Studia Sandomierskie” 17 (2010) 1-2, s. 197-221.

Szczur P., Problematyka społeczna w późnoantycznej Antiochii na podstawie nauczania homiletycznego Jana Chryzostoma, Lublin 2008.

Szczur P., Zasady pedagogii św. Jana Chryzostoma w homiliach antiocheńskich, [w:] Czasy Jana Chryzostoma i jego pasterska pedagogika, red. N. Widok, Opole 2008, s. 168-189 (Opolska Biblioteka Pedagogiczna, 105).

Szram M., Cnota pokory w nauczaniu greckich Ojców Kościoła IV wieku, Lublin 2014.

Szram M., Pokora $w$ walce z pycha - fundamentalny spór moralno-duchowy w rozumieniu Ojców Kapadockich i Jana Chryzostoma, „Vox Patrum” 33 (2013) 59, s. 531-345.

Szram M., Terminologia dotycząca pokory i pychy w pismach greckich Ojców Kościoła IV wieku, „Vox Patrum” 32 (2012) 58, s. 327-342.

Św. J. Chryzostom, o małżeństwie, wychowaniu dzieci i ascezie, przekł. W. Kania i in., red. J. Naumowicz, W. Krykowski, Kraków 2002.

Паскуато О., Миряни у Йоана Золотоустого. У Церкві, родині, громаді, Львів 2007.

Перлини Східних Отцуів, ред. Ю. Катрій, Львів $2006^{3}$. 